\title{
A DIGNIDADE NATURAL DO SER HUMANO E O PROBLEMA DO ABORTO
}

\author{
THE INNATE DIGNITY OF THE HUMAN BEING AND THE PROBLEM OF
}

ABORTION

\section{Resumo}

O texto oferece uma perspectiva de leitura para os vilipêndios praticados contra a vida não nascida, especificamente para o aborto provocado e para o aborto espontâneo decorrente do uso indevido de agrotóxicos no campo. Adota-se, para considerações acerca da dignidade humana e para a análise sistemática dos tipos de aborto, o ponto de vista do direito natural, a saber, que a inviolabilidade da vida humana é um princípio inerente à humanidade, cabendo ao Estado simplesmente assegurá-lo. Por fim, nega-se a existência do chamado "aborto legal" no Brasil, já que algumas hipóteses previstas no Código Penal não descriminalizam a prática, mas apenas excluem a sua punibilidade.

Palavras-chave: Direito natural. Direito à vida. Aborto. Saúde pública.

\begin{abstract}
The text offers a reading perspective to the vilification practiced against the unborn life, specifically to the abortion and to the miscarriage due to the misuse of pesticides in the field. For the considerations about the human dignity and to the systematic analysis of the species of abortion, it is adopted the natural right's point of view, namely that the sanctity of the human life is a principle inherent to humanity, belonging to the State just the act of assuring it. Lastly, it is denied the existence of the so called "legal abortion" in Brazil, since some hypotheses foreseen in the Brazilian Criminal Code do not decriminalize the act, just exclude its punishment.
\end{abstract}

Keywords: Natural law. Right to life. Abortion. Public health. 


\section{INTRODUÇÃO}

As discussões em torno do crime de aborto envolvem uma atmosfera ampla de polêmicas e controvérsias. Se, por um lado, sabe-se dos verdadeiros conflitos que existem no ordenamento jurídico e em ampla parcela da sociedade, questionando muitas vezes o papel da saúde pública no reconhecimento da independência da mulher, por outro, urge que se evidencie - especialmente neste século, que sucede um repleto de crimes praticados contra a humanidade - o princípio da dignidade da pessoa humana, inscrita na própria consciência dos homens e reconhecida pela Constituição Federal como um dos fundamentos da República Federativa do Brasil (cf. art. $1^{\circ}$, III).

Entra nesta gama de problemas a questão do aborto espontâneo no campo, que, neste caso, por mais que não dependa da vontade da mulher, ainda assim é consequência de decisões humanas. Antes, contudo, interessante apreender que embora a aplicação de agrotóxicos na lavoura seja uma atividade prioritariamente masculina, a maioria das famílias agricultoras tem mulheres pulverizando agrotóxicos. Os efeitos desta exposição, ainda mais nas regiões de predomínio do agronegócio, são, ao longo dos anos, devastadores, já que boa parte destes venenos contaminam os solos, água, plantações de vizinhos, florestas e, muitas vezes, áreas residenciais. Ou seja, até mesmo os consumidores se alimentam de produtos com altas taxas de resíduos de agrotóxicos. O que não dizer então das mulheres que laboram na área?

Para acirrar a discussão, análises feitas pela Anvisa anualmente têm demonstrado que diversos produtos de grande importância na alimentação dos brasileiros vêm apresentando resíduos de agrotóxicos acima dos limites permitidos e também de agrotóxicos proibidos. Todavia, apesar das inúmeras consequências danosas sobre a vida e saúde da população, limitar-nos-emos a discorrer sobre o envenenamento na cadeia da vida humana.

São inúmeros os relatos de pessoas que desenvolveram sérias doenças provocadas pelos agrotóxicos. Muitas deixam sequelas graves. Muitas outras são fatais. Há casos de abortos, assim como de bebês que nascem com defeitos congênitos pelo fato de a mãe ou o pai terem tido contato com agrotóxicos em sua vida, ou mesmo durante a gravidez (LONDRES, 2011, p. 25).

Destas constatações surgem diversas indagações e uma delas diz respeito ao uso descontrolado de agrotóxicos. Se são poluidores e podem causar agravos à saúde humana, ocasionando malformações, abortos, interferentes endócrinos e alguns tipos de câncer, por 
que então o Estado não faz valer a proteção e defesa da dignidade da pessoa humana e dos direitos da personalidade? Será mesmo que estes princípios não deveriam estar acima dos avanços tecnológicos e científicos experimentados pela humanidade?

Atualmente há um consenso, inclusive de cunho internacional, de dar maior proteção à vida e à saúde do trabalhador. Na tentativa de melhor adequar sua situação perante os órgãos internacionais, o Brasil ratificou a Convenção n. 155 da OIT, que estabelece normas e princípios a respeito da segurança e saúde dos trabalhadores, atitudes que poderiam ajudar na prevenção inclusive dos abortos ocorridos por consequências dos envenenamentos no campo. Todavia, sabe-se que a implantação desta política não é prioridade. Caso contrário, outra convenção - mais específica que aquela, inclusive -, a Convenção 184 - Sobre segurança e saúde na agricultura -, teria pelo menos sido ratificada.

Nota-se claramente que as autoridades não estão preocupadas com o assunto. Mesmo em se tratando de aborto espontâneo ocorrido na zona rural, o que de certa forma desembocaria na responsabilidade por omissão do Estado, por não ter promovido a proteção da saúde pública, o país está deixando de acolher os problemas gerados em torno desta economia "lucrativa". O uso intensivo de agrotóxicos tem sido impulsionado para atender a crescente demanda de produção agrícola. Isso tem colocado em risco a saúde dos produtores e trabalhadores, do meio ambiente e dos consumidores. Portanto, o processo de desenvolvimento econômico "ambicioso" é apontado como um dos principais fatores da degradação ambiental, influenciando as alterações dos perfis de saúde da população e até mesmo das futuras gerações.

É com esta atitude que o Estado e várias organizações empresariais transgridem a dignidade como valor supremo.

Enfatiza Arion Romita que:

a dignidade da pessoa humana atua como fundamento do princípio estruturante do Estado democrático de direito e, em consequiência, impregna a totalidade da ordem jurídica, espraia-se por todos os ramos do direito positivo e inspira não só a atividade legislativa como também a atuação do Poder Judiciário (2007, p. 267).

Na mesma direção, cita-se Cármen Lúcia Antunes Rocha, atual ministra do STF:

A constitucionalização do princípio da dignidade da pessoa humana modifica, em sua raiz, toda a construção jurídica: ele impregna toda a elaboração do Direito, porque ele é o elemento fundante da ordem constitucionalizada e posta na base do sistema. Logo, a dignidade da pessoa humana é princípio havido como superprincípio constitucional, aquele no qual se fundam todas as escolhas políticas 
estratificadas no modelo de Direito plasmado na formulação textual da Constituição (2004, p. 38).

Os casos concretos em que se coloca em xeque a questão da vida revestem-se de múltiplas dificuldades para o operador do Direito, mas nem por isto deve ele furtar-se de debater e fundamentar suas interpretações e tomadas de posição, tendo como base a legislação vigente e, em sua omissão, recorrendo à analogia, aos costumes e aos princípios gerais do direito, como preleciona o art. $4^{\circ}$ do Decreto-Lei n. 4657/42.

Cabe aqui uma breve introdução à expressão "princípios gerais do direito", sobre cujo significado os doutrinadores divergem. Silvio Rodrigues (2003, p. 22), por exemplo, reconhece que "muitos entendem que é aos princípios de direito natural que o legislador manda recorrer", muito embora ache que se deve dar ao termo um significado diverso. Abelardo Torré identifica-os com os "princípios de justiça, como fonte última a que deve recorrer para integrar o ordenamento jurídico" (apud DINIZ, 2000, p. 460). Maria Helena Diniz diz que "são normas de valor genérico que orientam a compreensão do sistema jurídico, em sua aplicação e integração, estejam ou não positivadas" (2000, p. 462). Ou seja, parece comum entre os doutrinadores a ideia de que os ditos "princípios gerais do direito" não se situam necessariamente dentro das normas positivadas pelo Estado. Mais: elas mesmas teriam seu fundamento último alhures.

É importante discutir o fundamento último da legislação positiva e este debate pode ganhar muito se os juristas voltarem a considerar a ideia de direito natural. Infelizmente, a partir do autor de "Teoria Pura do Direito", Hans Kelsen, este conceito começou a cair em ostracismo, sendo relegado para o sótão das faculdades de Direito. Foi constatando esta realidade que Ferraz Jr. (2013, p. 140) chamou a dicotomia direito natural-direito positivo de "uma dicotomia operacionalmente enfraquecida". Não que as contribuições de Kelsen para a filosofia do Direito devam ser menosprezadas. Ao contrário, "o conceito positivista de natureza e de razão, a visão positivista do mundo é, no seu conjunto, uma parcela grandiosa do conhecimento humano e da capacidade humana, à qual não devemos de modo algum renunciar" (BENTO XVI, 2011). Porém,

Uma concepção positivista de natureza, que compreende a natureza de modo puramente funcional, tal como a conhecem as ciências naturais, não pode criar qualquer ponte para a ética e o direito, mas suscitar de novo respostas apenas funcionais. Entretanto o mesmo vale para a razão numa visão positivista, que é considerada por muitos como a única visão científica. Segundo ela, o que não é verificável ou falsificável não entra no âmbito da razão em sentido estrito. Por isso, a ética e a religião devem ser atribuídas ao âmbito subjectivo, caindo fora do âmbito da razão no sentido estrito do termo. Onde vigora o domínio exclusivo da razão 
positivista - e tal é, em grande parte, o caso da nossa consciência pública -, as fontes clássicas de conhecimento da ética e do direito são postas fora de jogo. Esta é uma situação dramática que interessa a todos e sobre a qual é necessário um debate público; convidar urgentemente para ele é uma intenção essencial deste discurso (BENTO XVI, 2011).

Voltar ao direito natural, em um contexto de inúmeras possibilidades de positivação da injustiça ou de descriminalização de condutas cruéis e desumanas, significa devolver ao homem o valor inalienável que tem sua vida, que não pode ser destruída arbitrariamente sob hipótese alguma - seja ela de ordem afetivo-emocional, econômica ou mesmo supostamente científica -, correndo o risco de se aumentar ainda mais a ponte existente entre ética e direito.

Eis um dos objetivos principais deste trabalho: convidar urgentemente os operadores do direito para um debate público sobre a reintegração da ética e do direito. Da consideração e aceitação deste convite dependem em grande parte o futuro do biodireito e a solidez e força do edifício jurídico.

\section{A PROTEÇÃO AO NASCITURO}

Dar condições para que o ser humano possa se desenvolver ainda na barriga de sua mãe e assegurar-lhe o direito de nascer não foi sempre uma realidade na história do mundo. Com efeito,

$\mathrm{Na}$ antiguidade, entre gregos e romanos, o aborto ficava impune, ante o fato de considerarem o feto como pars viscerum matris, ou seja, parte integrante da mãe, que, então, podia livremente dispor de seu próprio corpo, reputandose, mais ou menos por volta do ano 200 d.C., o aborto feito por mulher casada como uma ofensa ao marido, no seu direito à prole esperada. Com isso a mulher solteira (nubile iuris sui) estava libertada para abortar (DINIZ, 2011, p. 58).

De fato, hoje, certos grupos advogam um malfadado "direito à escolha", contrapondo-o ao inviolável direito à vida, garantido não só pela Constituição brasileira, mas também por tratados internacionais, como o Pacto de San José da Costa Rica, do qual nosso país é signatário (cf. art. $4^{\circ}$ ). O conflito entre as duas frentes - os pro life e os pro choice - se evidencia especialmente nos Estados Unidos, no qual, desde 1973, quando a decisão Roe versus Wade uniformizou a jurisprudência no país, o aborto é legalizado.

$\mathrm{Na}$ verdade, a divergência se baseia em um entendimento distorcido da palavra "escolha". É claro que se pode dispor livremente do próprio corpo, mas até mesmo este exercício vê-se limitado a circunstâncias previstas em lei. Por exemplo, ressalvadas as 
situações exigidas pela medicina, uma pessoa - independentemente de ser homem ou mulher, já que a Constituição garante a igualdade jurídica dos sexos (cf. art. $5^{\circ}, \mathrm{I}$ ) - não pode dispor de si mesma, "quando importar diminuição permanente da integridade física, ou contrariar os bons costumes" (Lei n. 10.406/02, art. 13). O Código Civil brasileiro, prestando reconhecimento ao trabalho de vários juristas, também consagrou o direito à integridade física como direito personalíssimo da pessoa natural e, portanto, intransmissível e irrenunciável (cf. art. 11). Além do mais, a discussão do aborto, não diz respeito somente à integridade física da mulher, mas ao direito de outrem. Com efeito, os modernos avanços da biologia e a descoberta da genética não oferecem nenhum suporte a esta visão da Antiguidade de que o feto não passaria de pars viscerum matris, isto é, parte integrante do corpo materno.

Ao contrário,

\begin{abstract}
A ontogenia humana, isto é, o aparecimento de um novo ser humano, ocorre com a fusão dos gametas feminino e masculino, dando origem ao zigoto, com um código genético distinto do óvulo e do espermatozoide. A fetologia e as modernas técnicas de medicina comprovam que a vida inicia-se no ato da concepção, ou seja, da fecundação do óvulo pelo espermatozoide, dentro ou fora do útero. A partir daí tudo é transformação morfológico-temporal, que passará pelo nascimento e alcançará a morte, sem que haja qualquer alteração do código genético, que é singular, tornando a vida humana irrepetível e, com isso, cada ser humano único. (...) O feto é um ser com individualidade própria; diferencia-se, desde a concepção, tanto de sua mãe como de seu pai e de qualquer pessoa e, independentemente do que a lei estabeleça, é um ser humano (DINIZ, 2011, p. 50).
\end{abstract}

Significativo é que o nosso Código Penal tenha incluído o aborto no capítulo "dos crimes contra a vida".

O famoso médico francês Jérôme Lejeune, que descobriu a origem da síndrome de Down, assegura que "a fecundação é o marco do início da vida" e a conhecida Madre Teresa de Calcutá se questionava: "Se uma mãe pode matar seu próprio filho, o que resta então no Ocidente para ser destruído?” (apud DINIZ, 2011, p. 50).

\title{
2.1 O aborto espontâneo no campo
}

Não menos importantes são situações análogas que acabam ferindo o direito do nascituro à vida. Faz-se, aqui, referência específica ao processo de aborto espontâneo - ou mesmo de malformações advindas do processo de trabalho com atividades que geram grande risco à saúde, como no envolvimento com agrotóxicos, que, segundo várias pesquisas 
realizadas em todo o mundo, são verdadeiros vilões, levando-se em conta o alarmante número de vidas interrompidas ou mesmo aquelas que não seguiram o seu curso normal em decorrência de sua ação devastadora.

Em junho de 2010 o jornal argentino Página 12 publicou uma reportagem sobre a divulgação de um informe, elaborado por uma comissão criada pelo governo estadual do Chaco (no norte do país), analisando estatísticas de saúde em zonas de uso intensivo de agrotóxicos. Em uma década, triplicaram os casos de câncer em crianças e quadruplicaram os nascimentos de bebês com malformações. Isto se deu justamente no período em que aumentou consideravelmente o uso de agroquímicos Ainda segundo o estudo: na região (LONDRES, p. 54).

\begin{abstract}
Os casos de malformações congênitas em recém-nascidos cresceram ainda mais. Em uma década se quadruplicaram em todo o Estado do Chaco. No período de um ano, entre 1997 e 1998, houve no Chaco 24.030 nascimentos, dos quais 46 com malformações. Uma década depois, nos doze meses entre 2008 e 2009, foram registrados menos nascimentos: 21.808 , mas multiplicaram-se as malformações: 186 casos. O informe oficial destaca que se passou de um índice de 19,1 para 85,3 casos a cada 10 mil nascidos (LONDRES, p. 55).
\end{abstract}

O drama revela que a manifestação negativa dos agrotóxicos não tem fronteiras e, em todos os lugares onde são utilizados, há um retrocesso para a saúde de todos, inclusive dos nascituros que, mesmo antes de vir ao mundo, já estão expostos e vulneráveis.

\begin{abstract}
Já no Estado de Mato Grosso, devido ao crescimento do agronegócio, especificamente no município de Lucas do Rio Verde-MT, calcula-se que a população do município está exposta a 136,35 litros de agrotóxicos habitante/ano, trinta e sete vezes maior que a média nacional. Parte desses produtos utilizados na lavoura atinge a "peste" alvo, parte dissipa-se no ambiente podendo acumular-se no organismo humano ocasionando malformações, abortos, interferentes endócrinos e alguns tipos de câncer que podem ser detectados no leite humano (PALMA, 2011, p. 9)
\end{abstract}

A situação do município acima e de quase todo o estado de Mato Grosso é preocupante, reflete os interesses de alguns grupos econômicos, apoiados pelo governo estadual, que, preocupados tão somente com o lucro, realizam um desenvolvimento insustentável, com consequências danosas e degradantes tanto ao meio quanto à população. Não há qualquer vontade política em dar andamento aos estudos sobre as estatísticas apresentadas e suas consequências. Fosse o contrário, existiriam claramente normas e penalizações sobre o assunto. Ao que tudo indica, ao menos pela visão dos nossos legisladores, a degradação do ser humano ainda prevalecerá, mesmo que isto constitua afronta ao princípio da dignidade da pessoa humana, previsto em nossa Carta Magna. 


\subsection{No ordenamento jurídico brasileiro}

A Constituição da República Federativa do Brasil estabelece, no caput do art. $5^{\circ}$, que "todos são iguais perante a lei, sem distinção de qualquer natureza, garantindo-se aos brasileiros e aos estrangeiros residentes no País a inviolabilidade do direito à vida". Por ser da essência do próprio ser humano, este direito condiciona todos os demais direitos subjetivos que o homem virá a adquirir. Sejam os direitos sociais consagrados pelo art. $6^{\circ}$ da Carta Magna, como "a educação, a saúde, a alimentação, o trabalho, a moradia, o lazer, a segurança, a previdência social", sejam os direitos dos trabalhadores enumerados no art. $7^{\circ}$ do mesmo documento, sejam os próprios direitos individuais elencados após o direito à vida, a saber: "à liberdade, à segurança e à propriedade", nenhum deles pode ser exercido sem que antes seja reconhecido ao homem a inviolabilidade do seu direito de viver.

Quando se fala do direito à vida, pensa-se em duas dimensões que ele comporta: uma, positiva, diz respeito às condições necessárias para que ela se desenvolva e amadureça; outra, negativa, tange à sua proteção contra o arbítrio de outrem. É devido à garantia constitucional desta proteção que o Código Penal brasileiro tipifica, por exemplo, a conduta de "matar alguém" (art. 121) e "provocar aborto em si mesma ou consentir que outrem lho provoque" (art. 124, já referido supra). Com efeito, o nosso Código Civil, em seu art. 2º, embora tenha adotado, quanto ao surgimento da personalidade jurídica, a teoria natalista - isto é, "o seu surgimento, segundo a diç̧ão legal, ocorre a partir do nascimento com vida" (GAGLIANO; PAMPLONA FILHO, 2013, p. 129) -, protege, no mesmo artigo, "desde a concepção, os direitos do nascituro".

É evidente, como já exposto aqui, que o primeiro destes direitos postos a salvo pela Lei n. 10.406/02 é o direito à vida. Gagliano e Pamplona Filho, ao pontuarem as divergências existentes nesta área, lembram: "Ainda que o nascituro não seja considerado pessoa, a depender da teoria adotada, ninguém discute que tenha direito à vida, e não uma mera expectativa" (2013, p. 132). Ahrens preleciona que "o direito à vida principia com o primeiro germe de vida depositado no seio da mãe" (apud DINIZ, 2011, p. 51), em referência ao momento da concepção do ser humano.

Inúmeros são, ao mesmo tempo, os dispositivos legais que dão outras espécies de proteção ao nascituro. Tome-se como exemplo a Lei n. 11.804/08, objeto de deliberação legislativa relativamente recente, que "disciplina o direito a alimentos gravídicos e a forma como ele será exercido”. Mesmo este direito, porém, é importante destacar, não poderia ser exercido de forma alguma sem que antes fosse assegurado ao nascituro o direito de viver. 


\section{O ABORTO}

Antes de adentrar na seara das sanções penais ao crime do aborto, urge que se explique o seu significado. Ainda que possam parecer elementares estas lições, são importantes, a fim de se seguir uma metodologia clara e evitar imprecisões. Afinal, o que é o aborto? Quais são as causas que levam uma mulher a se submeter à prática ou mesmo a sofrer o chamado aborto espontâneo? Quais são as espécies tipificadas em nosso direito positivo?

A expressão "aborto" vem do latim abortus, aboriri, que significa "morrer, padecer", e designa, segundo Jesus (2001, p. 413), “a interrupção da gravidez com a consequente morte do feto (produto da concepção)". Neste mesmo sentido vai Mirabete (2001, p. 790) e Maria Helena Diniz, que o conceitua como "a interrupção da gravidez antes de seu termo normal, seja ela espontânea ou provocada, tenha havido ou não expulsão do feto destruído" (DINIZ, 2011, p. 54). Quanto às suas classificações, pode-se proceder por diversas vias, mas, aqui, limitar-nos-emos a classificar a prática em relação à sua causa, ao seu elemento subjetivo, à sua finalidade e, por fim, em relação à tipificação legal do aborto provocado.

\subsection{Classificação do aborto quanto à causa}

O que pode causar um aborto? Maria Helena Diniz classifica-o, quanto às causas, em três modalidades: aborto espontâneo, acidental e provocado. Nos dois primeiros, não há vontade deliberada da pessoa em praticar o ato. O aborto espontâneo, sobre o qual já se falou no correr deste texto, acontece quando uma doença ou certos defeitos estruturais embrionários impossibilitam o desenvolvimento do feto, causando sua inviabilidade. É neste tipo que se encaixam as críticas ao uso indiscriminado de agrotóxicos no campo, cujos efeitos se sentem seja em quem trabalha quotidianamente com a agricultura para sua subsistência, seja em grande parcela da população que consome os produtos cultivados no campo. Certas substâncias, quando em contato com o organismo da mulher, podem prejudicar não só a sua saúde, mas ser causa de abortos espontâneos, violando, deste modo, a dignidade da vida humana e a liberdade da mulher, que acolhia um filho em seu seio, mas teve aquela vida ceifada por uma eventualidade sórdida.

O aborto acidental, por sua vez, acontece "se inexistir qualquer propósito dirigido à interrupção do ciclo gravídico, provocada por um agente externo, como emoção violenta, susto, traumatismo (queda), sem que haja qualquer ato culposo, ou seja, negligência, imprudência ou imperícia” (DINIZ, 2011, p. 55). Enquadram-se nesta espécie os casos - mais 
comuns do que se pensa - de acidentes domésticos envolvendo gestantes, por exemplo. São situações em que a vida do embrião, ainda no seu início, se vê frágil e indefesa, e qualquer contato mais violento com o mundo externo pode se tornar uma fatalidade.

Quanto ao aborto provocado, trata-se da interrupção volitiva da gravidez. É deste tipo de aborto que se fala quando se faz referências às espécies legais que o penalizam. França destaca que "sempre que ocorrer intencionalmente a morte do concepto ou sua expulsão violenta seguida de morte está configurado o crime de aborto" (2001, p. 244). E Diniz, na mesma conjectura, diz que "o aborto provocado é uma prática criminosa em sua natureza e deve ser repudiado como contrário não só à consciência médica, ao espírito e à finalidade da medicina (...), como também ao comando contido no art. $5^{\circ}$ da Constituição Federal de 1988" (2011, p. 55).

\subsection{Classificação do aborto quanto ao elemento subjetivo}

A classificação da prática do abortamento de acordo com o elemento subjetivo diz respeito à vontade que induziu à morte da criança. Neste aspecto, o aborto pode ser: sofrido, quando realizado sem o consentimento da gestante - sendo, quando provocado, conduta tipificada no art. 125 do Código Penal; consentido, se cometido com a anuência da gestante, sendo conduta tipificada no art. 126 do mesmo diploma legal; e, por fim, procurado, caso a vontade da gestante for a principal envolvida no abortamento. Aqui podem enquadrar-se tanto a hipótese de autoaborto, prevista no art. 124 do Código Penal - "Provocar aborto em si mesma" - quanto a de aborto provocado por outrem, mas com o desejo da gestante de praticar o ato, prevista na continuação do mesmo art. 124 - "consentir que outrem lho provoque".

Neste caso, lembra Diniz (2011, p. 64),

\footnotetext{
A pena é mais grave do que a do autoaborto, pois o terceiro, apesar de contar com o beneplácito da gestante, além de dolosamente retirar a vida do nascituro, pode causar dano à incolumidade físico-mental da mãe, inclusive pondo em risco sua vida. Convém lembrar ainda que, em regra, quando o aborto é executado por terceiro, este dele faz sua profissão habitual, com intenção de lucro, praticando-o clandestinamente, em local inadequado, através de técnicas abortivas pouco eficazes ou de instrumentos não esterilizados convenientemente, que, em consequência, poderão acarretar septicemia.
}

Cabem aqui algumas considerações especiais sobre este problema que se revela extremamente presente na sociedade brasileira. 
Primeiro, está claro, a partir da analogia entre a norma do art. 124 e a do art. 126, que, ao contrário da alegação comum da militância defensora do aborto, há sim a preocupação com a saúde da mulher na hora de aplicar as penas devidas ao crime de abortamento. O fato de haver punição maior para quem pratica o aborto na mulher, mormente em condições subumanas e insalubres, do que para a mulher que consinta na realização da prática, evidencia o reconhecimento deste problema por parte de nosso ordenamento jurídico.

Segundo: pedir que a prática do abortamento seja amplamente realizada nos hospitais públicos, sob o pretexto de que "milhões de mulheres morrem todos os dias devido à prática de abortos clandestinos", trata-se de uma falácia. Nem se comenta aqui a falsidade destes números, já demonstrada algures, mas a imprecisão no apontamento do nexo de causalidade da sentença. Mulheres morrem devido a abortos clandestinos não porque eles sejam clandestinos, mas porque a prática do abortamento, em si, comporta inúmeros perigos não só para a vida da mulher, mas para a sua integridade física. Diniz (2011, p. 119) elenca vários desses perigos, como, por exemplo, o de infecção crônica, traumatismo, problemas no útero decorrentes de hemorragia, queda súbita de coagulação sanguínea, tétano, peritonite e frigidez sexual. França (2001, p. 250) comenta que "as complicações do aborto provocado são as mais variáveis e se mostram de considerável interesse médico-pericial, resultando lesões corporais de natureza leve ou grave, ou até mesmo a morte". E tudo isto sem citar os problemas psicológicos, sequelas que perduram por toda a vida. "O aborto fará a mulher mergulhar num estado psicótico, deixando profundas cicatrizes, pois transgrediu sua missão de guardiã da vida" (DINIZ, 2011, p. 120). Assim, descriminalizar totalmente o aborto - como querem alguns grupos - não só não é solução para o problema de saúde que representa o funcionamento de clínicas de aborto clandestinas, mas, ao contrário, só torna ainda pior a situação. Além disto, "as estatísticas têm demonstrado que nos países (...) onde o abortamento foi descriminalizado, não houve redução da incidência de abortos feitos às escondidas por pessoas não especializadas" (DINIZ, 2011, p. 124).

\subsection{Classificação do aborto quanto à sua finalidade}

Quanto à pretensão subjetiva da pessoa que realiza o aborto, este pode ser dividido em algumas espécies já consagradas pela doutrina.

A primeira delas é o chamado aborto terapêutico, não punido por nossa legislação penal (cf. art. 128, I). Também conhecido como aborto necessário, é realizado quando "não há outro meio de salvar a vida da gestante". A ideia que a ausência de punição pretende 
transmitir, neste caso, segundo França (2001, p. 245), é a da necessidade de se preservar um bem maior - no caso, "a vida da mãe". No entanto, o mesmo autor pontifica que "cada dia que passa, tão grande tem sido o avanço das ciências médicas que as indicações do aborto terapêutico diminuem, tornando raras as indicações indiscutíveis". Por este motivo, Diniz lembra que "tal aborto deveria ser chamado, segundo alguns autores, de desnecessário" (2011, p. 83). Geralmente, devido com justeza aos inúmeros progressos tecnológicos alcançados no campo da obstetrícia, encontram-se meios mais apropriados para se salvar a vida da gestante e, obviamente, jamais haverá certeza absoluta sobre a "necessidade" de se interromper uma gravidez para salvar a vida da mãe. Falar dos riscos de uma gestação chega a ser pleonástico, posto que toda gravidez comporta riscos e dificuldades. Ao mesmo tempo, advogar a superioridade da vida materna à vida do nascituro é, sem dúvida, uma posição problemática. "Se a norma constitucional assegura a vida humana, por que a do feto vale menos que a de sua mãe? Não deveria o direito à vida ser garantido a todos e de modo igual?" (DINIZ, 2011, p. 85). De fato, a nossa Carta Magna resguarda, no caput de seu art. $5^{\circ}$, como já mencionado supra, a inviolabilidade do direito à vida, sem mencionar qualquer atenuação de ordem etária ou familiar.

A segunda das espécies é o chamado aborto sentimental, sobre o qual também incide exclusão de punibilidade, conforme disposição do art. 128, II do Código Penal, in verbis:

\footnotetext{
Não se pune o aborto praticado por médico:

(...)

II - se a gravidez resulta de estupro e o aborto é precedido de consentimento da gestante ou, quando incapaz, de seu representante legal.
}

Este tipo de aborto ganha esta nomenclatura por ser fruto de uma decisão em grande medida motivada emocionalmente. Argumenta-se que a mulher não pode ser obrigada a lidar com a gestação do filho fruto de uma violência, que ela não planejou e não quis absolutamente que fosse concebido. Na avaliação de França (2001, p. 246),

\begin{abstract}
Mesmo com tais argumentos, essa forma de aborto é difícil de ser justificada. Seria garantir ao médico o direito de atentar contra uma vida. Se não aceitamos, por tradição e por índole, a pena de morte de um criminoso, por mais cruel e hediondo que seja o crime, como iríamos permitir a morte de um inocente? Toda sociedade e toda forma de direito assentam-se no respeito inviolável à vida humana, e esse respeito deve estender-se desde a fecundação até o último alento da criatura. Essa inviolabilidade não é apenas uma convenção, mas o fundamento de todo o Direito.
\end{abstract}

Não se pretende com isto minimizar ou mesmo ignorar completamente a terrível dor que sofre quem é vítima de violência sexual. As lembranças deste ato verdadeiramente 
abusivo e criminoso podem deixar marcas para o resto da vida. No entanto, nem esta realidade dramática pode justificar, nas palavras do Papa João Paulo II (1995), “a supressão deliberada de um ser humano inocente”. Na mesma linha, Diniz (2011, p. 89) preleciona: “O estupro é terrível e muito doloroso, por isso, ilógico seria 'apagá-lo', como se isso fosse possível, da memória da vítima com uma outra violência não menos atroz, que é a destruição da vida de um ser humano".

Outra espécie de aborto considerada pelos juristas é o chamado aborto eugênico, cuja punibilidade foi excluída no caso de comprovação médica de anencefalia, de acordo com a decisão referente à Arguição de Descumprimento de Preceito Fundamental n. 54, do Supremo Tribunal Federal. A anencefalia é uma doença diagnosticada geralmente entre o $3^{\circ}$ e o $4^{\circ}$ mês de gravidez, consistindo na má formação do tubo neural e, consequentemente, na ausência de parte do cérebro e da calota craniana. Trata-se de uma enfermidade quase sempre fatal, podendo o feto por ela acometido viver dias, meses ou, em situações extraordinárias, mais de um ano, como foi o caso da menina Marcela de Jesus, uma vítima da doença que morreu com pouco mais de 1 ano e 8 meses. Ora, se esta criança chegou a falecer, não resta dúvidas de que estava viva e, portanto, tinha resguardados os seus direitos personalíssimos.

Assim, data maxima venia, não podemos concordar com a afirmação do ministro Carlos Ayres Britto, consignada em seu voto durante o julgamento da ADPF 54, de que "o feto anencéfalo é uma crisálida que jamais, em tempo algum, chegará ao estádio de borboleta porque não alçará voo jamais" (BRASIL, p. 259). Quem poderá dizer que o curto período de vida da menina Marcela, e de tantas outras crianças que sobreviveram às vezes por poucos minutos, não valeu a pena, ou que somente se chega "ao estádio de borboleta" em um período determinado da vida? Não seria uma medida arbitrária encurtar a existência de um ser humano pela mera inferência de que será breve o seu alçar voo?

Junto a estas perguntas, permanecem válidas as considerações do ministro Cezar Peluso, ao julgar o mérito do mesmo caso, in verbis:

É que, nessa postura dogmática, ao feto, reduzido, no fim das contas, à condição de lixo ou de outra coisa imprestável e incômoda, não é dispensada, de nenhum ângulo, a menor consideração ética ou jurídica, nem reconhecido grau algum da dignidade jurídica e ética que lhe vem da incontestável ascendência e natureza humanas. Essa forma odiosa de discriminação, que a tanto equivale, nas suas consequências, a formulação criticada, em nada difere do racismo, do sexismo e do chamado especismo. Todos esses casos retratam a absurda defesa e absolvição do uso injusto da superioridade de alguns (em regra, brancos de estirpe ariana, homens e seres humanos) sobre outros (negros, judeus, mulheres e animais, respectivamente). No caso do extermínio do anencéfalo, encena-se a atuação avassaladora do ser poderoso superior que, detentor de toda a força, inflige a pena de morte ao incapaz de pressentir a agressão e de esboçar-lhe qualquer defesa. Mas o simples e decisivo fato 
de o anencéfalo ter vida e pertencer à imprevisível espécie humana garante-lhe, em nossa ordem jurídica, apesar da deficiência ou mutilação (...), que lhe não rouba a inata dignidade humana, nem o transforma em coisa ou objeto material desvalioso ao juízo do Direito e da Constituição da República (BRASIL..., p. 383).

Com efeito, o grande problema da aceitação do abortamento de fetos anencefálicos está na abertura que esta pode trazer a outras formas de aborto eugênico e, em última instância, ao próprio infanticídio de recém-nascidos com má formação física (FRANÇA, 2001, p. 247). No mesmo entendimento, Diniz (2011, p. 73) ressalta que "o aborto eugenésico é um retrocesso, pois não passa de uma eutanásia de seres humanos na fase intrauterina, que em nada se diferencia (...) da matança de recém-nascidos imperfeitos praticada na era pagã em Esparta”.

Os doutrinadores têm o hábito de citar outras espécies de aborto, nas quais não adentraremos, por ser um terreno no qual fica explícita a tentativa de banalização da dignidade da vida humana e da sua inviolabilidade, garantidas - sempre vale repetir constitucionalmente.

\subsection{O aborto sob o prisma legal}

Partindo à classificação do aborto de acordo com as previsões legais sancionadas no Código Penal brasileiro, pretende-se, agora, dar resposta a algumas sentenças que têm sido jogadas ostensivamente nos meios de comunicação, revestindo a discussão da penalização do aborto de múltiplas dificuldades e conduzindo muitas vezes a um caminho no qual o debate social e jurídico sadio fica ou prejudicado ou totalmente impossibilitado.

Sob o prisma da lei, a prática do abortamento no Brasil recebe dois tratamentos, como se pode concluir da leitura dos art. 124, 125, 126, 127 e 128 do Decreto-Lei n. 2.848/40. Os quatro primeiros artigos tratam, respectivamente, da punição de autoaborto, aborto sofrido, aborto provocado por terceiro com anuência da gestante e das formas qualificadas dos dois últimos casos.

O art. 128, por outro lado, traz os casos em que "não se pune o aborto praticado por médico". Tratam-se, como tem consagrado o linguajar midiático comum, de casos de "aborto legal'”?

A resposta para esta pergunta transcende a esfera do Direito Penal. O termo "aborto legal" supõe uma previsão legislativa que autorize a prática do abortamento. Ora, considerando que há normas infraconstitucionais - como o Código Civil, já citado - e até 
mesmo constitucionais - o inciso III do art. $1^{\mathrm{o}}$ e o caput do art. $5^{\circ}$ - protegendo a vida humana, não se pode falar em "aborto legal" coerentemente no ordenamento jurídico brasileiro. "A matéria específica de uma Constituição é dizer como devem ser feitas todas as leis (as normas gerais)" (FERRAZ JR., 2013, p. 196) e o seu art. 60, que define justamente como deve ocorrer o processo legislativo, prevê, no $\S 4^{\circ}, \mathrm{IV}$, in verbis:

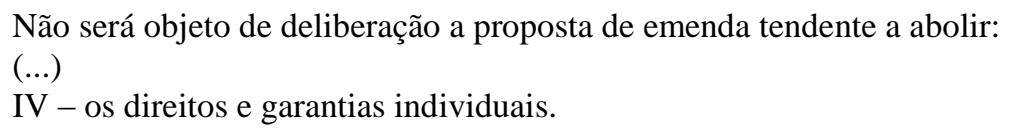

No Brasil, portanto, por decisão do poder constitucional originário, não é cabível a utilização do termo "aborto legal”, como se a prática pudesse ser objeto de direito subjetivo. Nem uma emenda constitucional poderia "abolir" o direito à vida, institucionalizando o aborto no Brasil, posto que a sua inviolabilidade é cláusula pétrea.

Como enfrentar, então, a questão do art. 128, que não pune as espécies de aborto ditas "necessária" e "sentimental" - já analisadas supra?

Encontramo-nos diante de um crime sem pena, perfeitamente possível no Código Penal vigente (cf. art. 23, 121, § $5^{\circ}$, e 181). Nos casos de estupro e risco de vida para a mulher, portanto, continua havendo delito, mesmo que não receba sanção punitiva por parte do Estado. No entender de Nélson Hungria, citado por Diniz (2011, p. 82), "a ilicitude de um fato não deriva da sanctio, mas do praeceptum da norma penal. No preceito é que se encerra o juízo de reprovação, que inspira o legislador na incriminação de tal ou qual fato". Nas palavras de Diniz:

\footnotetext{
No Brasil não há nem poderia haver aborto "legal", ante o princípio constitucional do direito ao respeito à vida humana, consagrado em cláusula pétrea $\left(\mathrm{CF}\right.$, art $\left.5^{\circ}\right)$. Portanto, se o art. 128 do Código Penal estipulasse que não há crime em caso de aborto para salvar a vida da gestante ou de gestação advinda de estupro, estaria eivado de inconstitucionalidade, pois uma emenda constitucional, e muito menos uma lei ordinária, não poderia abrir exceção ao comando contido no art. $5^{\circ}$ da Constituição Federal de 1988. É indubitável que o aborto sem pena, previsto no art. 128, é um delito (2011, p. 82).
}

Assim sendo, não há de se falar de "aborto legal" no Brasil, mas sim de casos de exclusão da punibilidade. Pode parecer, à primeira vista, uma mera preocupação técnica e, por isso, pouco importante. No entanto, a disseminação desta expressão pode firmar um entendimento diferente da vontade do legislador penal, que conformou as leis do Código Penal à inalienabilidade da vida humana. 
Já no que se refere ao aborto espontâneo no caso de envenenamento das mulheres que laboram na zona rural, é incompreensível que as entidades envolvidas nesta situação permaneçam impunes, pois está cristalina a responsabilidade tanto dos fortes grupos econômicos, quanto do Estado em um problema que é de saúde pública. Assegura a Constituição Federal que além de ser um direito social (art. $6^{\circ}$ ), a saúde é direito de todos e dever do Estado (art. 196), portanto, são normas de ordem pública. Volta-se para quaisquer pessoas e atribui às normas constitucionais "a consciência de que o direito à vida, como matriz de todos os demais direitos fundamentais do homem é que há de orientar as formas de atuação no campo da tutela do meio ambiente" (SILVA, 1990, p. 709).

A influência do ambiente de trabalho sobre a saúde humana, notadamente da mulher, é inquestionável e tem relação direta com a saúde pública, essencial a todos e garantida pela própria Carta Magna em seu art. 196.

Oportuno destacar que assunto provoca grandes discussões, sendo uma delas se o cidadão comum teria direito a exigir judicialmente prestações de saúde do Estado no polo passivo. No entendimento da douta professora e constitucionalista Cármen Lúcia Antunes Rocha,

\begin{abstract}
A eficácia deste direito, pelos termos taxativos ensaiados no texto, independe de eleição de políticas ou de escolha de condutas estatais. A sua exigência respalda-se no documento constitucional, podendo qualquer pessoa valer-se do seu direito utilizando-se da via que o torne eficiente à sua necessidade. Assim é que, inexistindo em determinada localidade, por exemplo postos de prestação pública de serviços eficientes de saúde à disposição das pessoas, podem elas, se necessitar dos mesmos, se dirigirem a postos, clínicas ou hospitais particulares e exigir que o Estado satisfaça às cobranças feitas por esta instituição, inclusive aquelas de natureza pecuniária, decorrentes do uso do serviço. (...) Estipulou-se, destarte, de maneira incondicional, a obrigação pública da prestação dos serviços de promoção, proteção e recuperação de saúde a todos (1988, p. 46).
\end{abstract}

Por fim, destaca Oliveira (2011, p. 129):

Entendemos que a interpretação sistemática da Constituição da República deixa evidente a caracterização do direito subjetivo público à saúde, exigível do Estado. $\mathrm{O}$ art. $6^{\circ}$ relaciona diversos direitos sociais: educação, saúde, trabalho, moradia, lazer, segurança, previdência social, proteção à maternidade e à infância e a assistência aos desamparados. Destes, foram destacadas apenas a educação e saúde, estabelecendo a Constituição, portanto, um degrau a mais, pois além de dever do Estado é direito de todos (art. 196 e 205). Logo, nessas duas hipóteses estão perfeitamente caracterizados o sujeito ativo, o objeto e o sujeito passivo da obrigação, com todos os elementos para a formação do vínculo juridicamente exigível. Também não se deve perder de vista o princípio de que a todo direito corresponde uma ação que o assegura. 
O fato é que nesses casos apontados - abortos espontâneos e mesmo malformações do feto -, as mazelas provenientes do intensivo envenenamento do organismo humano não podem ficar impunes. Mesmo que na seara cível, deverão efetivamente surtir efeitos, posto que o Estado é, em sua essência, o protetor da nossa Constituição Federal, sendo um de seus primórdios e cláusula pétrea o respeito à dignidade da pessoa humana.

\section{CONCLUSÃO}

Chegando, por fim, às linhas conclusivas, cabe recordar as perspectivas propostas na introdução deste artigo. Além de expor e enfrentar os numerosos conflitos existentes na seara jurídica no que diz respeito à proteção do nascituro e aos tipos legais que punem a violação do seu direito à vida, procurou-se firmar o entendimento de que o respeito à dignidade humana transcende as legislações positivas; de que este - para recorrer também à filosofia do direito se trata de uma garantia da lei natural.

Estamos conscientes de que esta não é a posição que se convencionou adotar em grande parte da academia. Enquanto alguns escritores se perguntam "até quando pensaremos a dignidade sob o ponto de vista axiológico e não dentro de um contexto normativo e procedimentalista" (NAVES; SÁ, 2009, p. 51), firmamos o entendimento de que é preciso reintegrar a ética e o direito, sob o risco de legarmos para as próximas gerações normas jurídicas despidas de imperativo moral, cuja hermenêutica sirva menos como objeto de legítima interpretação que como instrumento a serviço de ideologias - entendidas aqui como falsas consciências da realidade. Isto não significa desprezar a literatura construída no último século, especialmente a partir de Hans Kelsen, cuja obra ajuda a penetrar de modo profundo no difícil mundo jurídico e oferece uma vasta contribuição para os operadores do direito até hoje. O que não se pode fazer é limitar o fenômeno jurídico, de cuja amplitude o homem moderno tanto se regozija, a uma compreensão filosófica unilateral. Por isso a insistência em um debate sobre o direito natural, que já o filósofo Cícero, ainda antes de Cristo, definia como “a suprema razão ínsita na natureza” (apud CRETELLA JR., 1993, p. 114).

Revalorizando o direito natural, abre-se o caminho para firmar aquele que é um dos fundamentos de nossa República: o princípio da "dignidade da pessoa humana" (art. 1º III), que deve ser assegurada desde o momento da concepção: "Quando os 23 cromossomos masculinos se encontram com os 23 cromossomos da mulher, todos os dados genéticos que definem o novo ser humano já estão presentes. A fecundação é o marco do início da vida (...), 
qualquer método artificial para destruí-la é um assassinato" (Jérôme Lejeune apud DINIZ, 2011, p. 50).

\section{REFERÊNCIAS}

BENTO XVI. Discurso em visita ao Parlamento no Palácio do Reichstag de Berlim. Santa Sé: $22 \quad$ set. $2011 . \quad$ Disponível em:<http://www.vatican.va/holy_father/benedict_xvi/speeches/2011/september/documents/hf _ben-xvi_spe_20110922_reichstag-berlin_po.html>. Acesso em: 03 set. 2013.

BRASIL. Supremo Tribunal Federal. Arguição de Descumprimento de Direito Fundamental 54. Disponível em: <http://www.osconstitucionalistas.com.br/wpcontent/uploads/acordao-ADPF-54.pdf>. Acesso em: 03 set. 2013.

CRETELLA JR., José. Curso de filosofia do direito. 4. ed. Forense: Rio de Janeiro, 1993.

DINIZ, Maria Helena. Compêndio de introdução à ciência do direito. 12. ed. São Paulo: Saraiva, 2000.

DINIZ, Maria Helena. O estado atual do biodireito. 8. ed. São Paulo: Saraiva, 2011

FERRAZ JR., Tércio Sampaio. Introdução ao Estudo do Direito. 7. ed. São Paulo: Atlas, 2013.

FRANÇA, Genival Veloso de. Medicina Legal. 6. ed. Guanabara Koogan: Rio de Janeiro, 2001 .

GAGLIANO, Pablo Stolze; PAMPLONA FILHO, Rodolfo. Novo curso de direito civil, volume 1: parte geral. 15. ed. São Paulo: Saraiva, 2013.

JESUS, Damásio E. de. Código penal anotado. 11. ed. São Paulo: Saraiva, 2001.

JOÃO PAULO II. Carta encíclica Evangelium vitae. Santa Sé: 25 mar. 1995. Disponível em <http://www.vatican.va/holy_father/john_paul_ii/encyclicals/documents/hf_jpii_enc_25031995_evangelium-vitae_po.html>. Acesso em: 03 set. 2013.

Menina anencéfala morre com 1 ano e 8 meses em Franca (SP). Folha Online, 02 ago. 2008. Disponível em: <http://www1.folha.uol.com.br/folha/cotidiano/ult95u428993.shtml>. Acesso em: 03 set. 2013.

LONDRES, Flavia. Agrotóxicos no Brasil: um guia para ação em defesa da vida. Rio de Janeiro: AS-PTA, 2011.

MELO, Raimundo Simão de. Direito ambiental do trabalho e a saúde do trabalhador. 4. ed. São Paulo: LTr, 2010.

MIRABETE, Julio Fabbrini. Código penal interpretado. 2. ed. São Paulo: Atlas, 2001. 
NAVES, Bruno Torquato de Oliveira; SÁ, Maria de Fátima Freire de. Manual de biodireito. Belo Horizonte: Del Rey, 2009.

OLIVEIRA, Sebastião Geraldo de. Proteção Jurídica à Saúde do Trabalhador. 6. ed. São Paulo, LTr, 2011.

PALMA, Danielly Cristina de Andrade. Agrotóxicos em leite humano de mães residentes em Lucas do Rio Verde - MT. Cuiabá, 2011. Disponível em: $<$ http://www.mcpbrasil.org.br/biblioteca/agrotoxicos/doc_view/41-agrotoxicos-em-leitehumano-de-maes-residentes-em-lucas-do-rio-verde-mt>. Acesso em: 08 set. 2013.

ROCHA, Cármen Lúcia Antunes. O direito à vida digna. Belo Horizonte: Fórum, 2004.

ROCHA, Cármen Lúcia. O serviço público de saúde no direito brasileiro. Brasília: Organização Pan Americana de Saúde, 1988.

ROCHA, Julio Cesar de Sá da. Direito ambiental do trabalho: mudanças de paradigma na tutela jurídica à saúde do trabalhador. São Paulo: Atlas, 2013.

RODRIGUES, Silvio. Direito civil, v. 1. Parte geral. 33. ed. São Paulo: Saraiva, 2003.

ROMITA, Arion Sayão. Direitos fundamentais nas relações de trabalho. 2. ed. São Paulo: LTr, 2007.

SILVA, José Afonso da. Curso de direito constitucional positivo. 6. ed. São Paulo: RT, 1990. 